\title{
Ursolic acid isolated from Isodon excisoides induces apoptosis and inhibits invasion of GBC-SD gallbladder carcinoma cells
}

\author{
HUIPING CHEN $^{1^{*}}$, XIUJUAN WU $^{2^{*}}$, YITAO DUAN $^{1}$, DEXIAN ZHI $^{3}$, MIN ZOU $^{1}$, ZHIHONG ZHAO $^{1}$, \\ XIAOJUN ZHANG ${ }^{1}$, XIAOANG YANG $^{1}$ and JIANYING ZHANG ${ }^{1}$ \\ ${ }^{1}$ Institute of Medical and Pharmaceutical Sciences, Zhengzhou University, Zhengzhou, Henan 450052; \\ ${ }^{2}$ Department of Cardiology, Zhengzhou University People's Hospital (Henan Provincial People's Hospital), Zhengzhou, \\ Henan 450003; ${ }^{3}$ Tianjin Key Laboratory of Food and Biotechnology, School of Biotechnology and Food Science, \\ Tianjin University of Commerce, Tianjin 300134, P.R. China
}

Received April 21, 2018; Accepted March 21, 2019

DOI: $10.3892 / 01.2019 .10397$

\begin{abstract}
Gallbladder carcinoma (GBC) is a relatively rare but terminal malignancy, and drug/chemical development is an important aspect of prevention and treatment of GBC. Ursolic acid (UA), a pentacyclic triterpenoid, has been reported to exhibit various pharmaceutical effects. In the present study, the antiproliferative and anti-invasive effects of UA and the associated mechanisms in GBC were examined. UA was isolated from Isodon excisoides. The GBC cells (GBC-SD and NOZ) were treated with UA and subjected to a Cell Counting Kit-8 assay. The GBC-SD cells were subsequently selected for an Annexin V-FITC/propidium iodide assay, Transwell chamber assay, $\mathrm{RT}^{2}$ profiler polymerase chain reaction (PCR) array and western blot analysis. The results indicated that UA inhibited the proliferation and invasion and induced the apoptosis of GBC-SD cells in a dose-dependent manner. Furthermore, the PCR arrays demonstrated that there were 24 differentially expressed genes between the UA-treated and untreated groups. These differentially expressed genes suggested that UA induced the apoptosis of GBC-SD cells through activation of the cell extrinsic pathway. According to Kyoto Encyclopedia of Genes and Genomes pathway analysis of these differentially expressed genes, the suppression of nuclear factor (NF)- $\kappa \mathrm{B}$ and protein kinase $\mathrm{B}$ (Akt) signaling pathways was further validated. In summary, UA induces the apoptosis and inhibits the invasion of GBC-SD cells, which may be associated with
\end{abstract}

Correspondence to: Professor Jianying Zhang or Dr Yitao Duan, Institute of Medical and Pharmaceutical Sciences, Zhengzhou University, 40 Daxue Road, Erqi, Zhengzhou, Henan 450052, P.R. China

E-mail: jzhang@utep.edu

E-mail: duanyitao@126.com

*Contributed equally

Key words: ursolic acid, gallbladder carcinoma, apoptosis, invasion, nuclear factor- $\kappa \mathrm{B}$, protein kinase $\mathrm{B}$ the suppression of $\mathrm{NF}-\kappa \mathrm{B}$ and Akt signaling pathways. These results may offer a potential therapeutic strategy for the chemoprevention or chemotherapy of GBC in humans.

\section{Introduction}

Gallbladder carcinoma (GBC) is the most common malignant tumor of the biliary tract and one of the common malignant tumor types of the gastrointestinal tract (1). GBC is infrequent in the majority of developed countries, but common in certain specific geographical regions of developing countries, including northern India, South Karachi in Pakistan and eastern Europe (2). GBC is characterized by late diagnosis, metastasis and recurrence which occur readily, and poor prognosis and survival rates (2-4). Surgery is considered the only curative therapy for GBC. However, at diagnosis, $<20 \%$ of patients are suitable candidates for surgical treatment (4). GBC should be treated with systemic chemotherapy, and drug/ chemical development is important for the prevention and treatment of GBC.

Antitumor promotion with phytochemicals is currently regarded as an efficient and reliable strategy for cancer chemoprevention and therapy. The genus Isodon (formerly Rabdosia) comprising $\sim 150$ species of undershrubs, subundershrubs and perennial herbs, is found throughout the world, primarily in tropical and subtropical Asia (5). Several Isodon species are widely used in popular Chinese folk medicine for the treatment of bacterial infections, inflammation, cancer and hepatotoxicity (5). A large number of secondary metabolites with diverse biological activities have been isolated from this species. These chemical constituents include diterpenoids, triterpenoids and flavonoids (6-8). In the present study, ursolic acid (UA; Fig. 1A), a pentacyclic triterpenoid, was isolated from Isodon excisoides. UA has been reported to exhibit various pharmaceutical effects, including anticancer, antiangiogenic, antioxidant, anti-inflammatory, antibacterial, hepatoprotective, cardioprotective, antihyperlipidemic and hypoglycemic activities, among others $(9,10)$. The anticancer effects of UA are mediated by suppression of the phosphoinositide-3-kinase $(\mathrm{PI} 3 \mathrm{~K}) /$ protein kinase $\mathrm{B}(\mathrm{Akt})$, nuclear factor $(\mathrm{NF})-\kappa \mathrm{B}$ and signal transducer and activator of transcription 3 pathways 

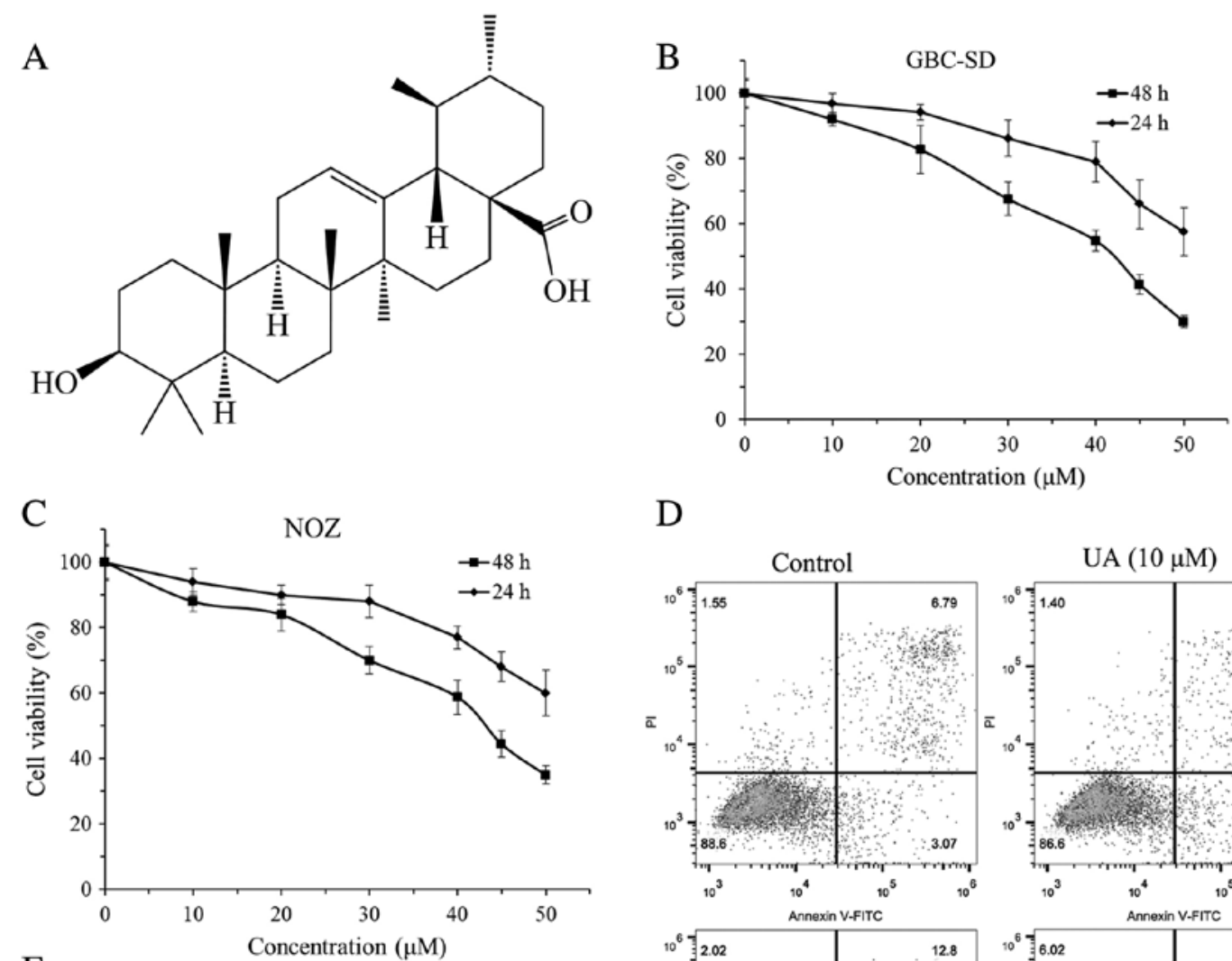

$\mathrm{D}$
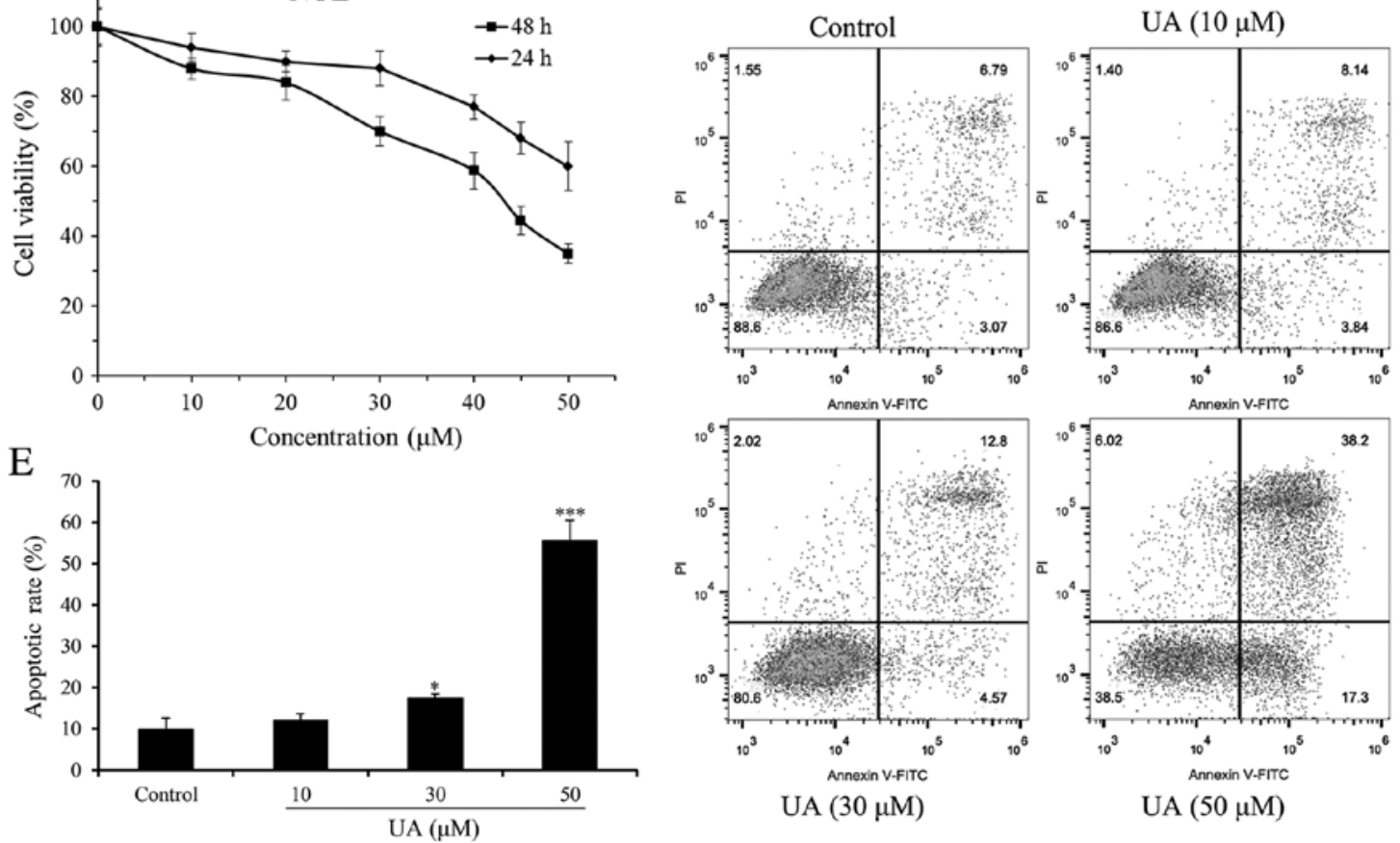

Figure 1. Effects of UA on the proliferation and apoptosis of human GBC cells. (A) Structure of UA. Effect of UA on the proliferation of (B) GBC-SD and (C) NOZ cells. Cell survival was determined by Cell Counting Kit-8 assay and calculated relative to the vehicle-treated cells ( $0 \mu \mathrm{M} \mathrm{UA})$. GBC-SD and NOZ cells were inhibited in a time-dependent manner at 24 and $48 \mathrm{~h}$ after UA exposure. (D) UA induced apoptosis of GBC-SD cells. Apoptosis of GBC-SD cells induced by different concentrations of UA $(0,10,30$ and $50 \mu \mathrm{M})$ for $24 \mathrm{~h}$, evaluated using flow cytometry with an Annexin V-FITC/PI assay. (E) Quantification of apoptotic rates. Data are presented as the mean \pm standard deviation from three independent experiments. ${ }^{*} \mathrm{P}<0.05$ and ${ }^{* * * *} \mathrm{P}<0.001$, vs. control group $(0 \mu \mathrm{M})$. UA, ursolic acid; PI, propidium iodide.

with their regulated gene products, including cyclin D1, Bcl-2, Bcl-xL, survivin, myeloid cell leukemia-1 and vascular endothelial growth factor (11). In addition, He et al (12) reported that there were 611 proteins possibly interacting with UA and $>49$ functional clusters responding to UA. Numerous studies have suggested that UA is a promising sensitizer for cancer therapy (11). Previous evidence has revealed that UA inhibits the growth of GBC cells through inducing cell cycle arrest and apoptosis (13). However, the anti-invasive effect of UA and the associated mechanism in GBC remain to be fully elucidated. Therefore, the present study aimed to investigate the antiproliferative and anti-invasive effects of purified UA in the GBC-SD human GBC cell line in vitro. The results will assist in expanding current understanding of the anticancer effect and mechanism of UA. Furthermore, the results may contribute to the development of UA as a potent anticancer agent for GBC.

\section{Materials and methods}

Plant material, cells and reagents. The aerial parts of I. excisoides were collected from Luanchuan County in Henan Province, China in July 2014 and authenticated by Professor Jicheng Li of Zhengzhou University (Zhengzhou, China). A voucher specimen (no. 20140706167LY) was deposited in the herbarium of the College of Pharmacy, Zhengzhou University. The human GBC cell lines GBC-SD (cat. no. CC2502) and NOZ (cat. no. CC2501), which exhibit correct short tandem repeat profiles, were originally purchased from Guangzhou Cellcook Biotech Co., Ltd (Guangzhou, China) and stored in the Henan Key Laboratory for Pharmacology of Liver Diseases (Institute of Medical and Pharmaceutical Sciences, Zhengzhou University, Zhengzhou, China). The reagents used included RPMI-1640 medium (cat. no. SH30809.01) and high-glucose Dulbecco's modified Eagle's medium 
(DMEM; cat. no. SH30022.01; Hyclone; GE Healthcare Life Sciences, Logan, UT, USA), fetal bovine serum (FBS; cat. no. 900-108; Gemini Bio Products, West Sacramento, CA, USA), Cell Counting Kit-8 (CCK-8; cat. no. CK04; Dojindo Molecular Technologies Inc., Shanghai, China), Annexin V-FITC/Propidium iodide (PI) Apoptosis Detection kit (cat. no. 70-AP101-60; Multi Sciences Biotech Co., Ltd., Hangzhou, China), Transwell chambers with polycarbonate filters $(8-\mu \mathrm{m}$ pore size; cat. no. 3422; Corning, Inc., Corning, NY, USA), Matrigel (cat. no. 356234; BD Biosciences, Franklin Lakes, NJ, USA), TRIzol reagent (cat. no. 15596-026; Invitrogen; Thermo Fisher Scientific, Inc., Waltham, MA, USA), PrimeScript ${ }^{\mathrm{TM}}$ RT Reagent kit (cat. no. DRR037A; Takara Biotechnology Co., Ltd., Dalian, China), RT ${ }^{2}$ Profiler 'human apoptosis' polymerase chain reaction (PCR) arrays (cat. no. PAHS-012Z) and $\mathrm{RT}^{2}$ Profiler 'human extracellular matrix and adhesion molecules' PCR arrays (cat. no. PAHS-013Z; Qiagen, Inc., Valencia, CA, USA), EvaGreen 2X qPCR MasterMix-No Dye kit (cat. no. MasterMix-S; Applied Biological Materials, Richmond, BC, Canada), Dimethylsulfoxide (DMSO; cat. no. D8371), bovine serum albumin (BSA; cat. no. A8010), RIPA lysis buffer (cat. no. R0020; Solarbio Science and Technology, Beijing, China), phosphorylated (phosphor)-NF-кB p65 (Ser536) antibody (cat. no. 3033), NF-кB p65 antibody (cat. no. 3034), phospho-Akt (Ser473) antibody (cat. no. 9271), Akt antibody (cat. no. 9272; Cell Signaling Technology, Inc., Beverly, MA, USA) and GAPDH monoclonal antibody (cat. no. 60004-1-lg; ProteinTech Group, Inc., Chicago, IL, USA). Other chemicals and reagents were of analytical grade.

Extraction, isolation and purification of UA from I. excisoides. The dried and powdered aerial parts of I. excisoides $(3 \mathrm{~kg})$ were extracted with anhydrous ether $(12 \mathrm{~L})$. The extract was then filtered and evaporated in a rotatory evaporator under reduced pressure. The concentrated residue $(89 \mathrm{~g})$ was dissolved in methanol $(3.6 \mathrm{~L})$ and activated carbon $(108 \mathrm{~g})$ was added. The mixture was heated under reflux and further filtered and evaporated to produce a crude product $(71 \mathrm{~g})$. The crude product was then successively separated by silica gel chromatographic column and Sephadex LH-20 column chromatography, giving a compound (56 mg). This compound was identified as UA on the basis of its mass and nuclear magnetic resonance spectra. UA (ursolic acid, $\mathrm{C}_{30} \mathrm{H}_{48} \mathrm{O}_{3}$ ): HR-EIMS m/z 456.3608 (456.3603 calcd. for $\left.\mathrm{C}_{30} \mathrm{H}_{48} \mathrm{O}_{3}\right)$; ${ }^{1} \mathrm{H}-\mathrm{NMR}\left(\mathrm{C}_{5} \mathrm{D}_{5} \mathrm{~N}\right.$, $400 \mathrm{MHz}): \delta 5.52(1 \mathrm{H}, \mathrm{t}, J=3.5 \mathrm{~Hz}, \mathrm{H}-12), 3.48$ (1H, dd, $J=9.9$, $5.4 \mathrm{~Hz}, \mathrm{H}-3 \alpha), 2.68$ (1H, d, $J=11.4 \mathrm{~Hz}, \mathrm{H}-18), 1.27,1.05,0.91$, 1.08 and 1.25 (each $3 \mathrm{H}, \mathrm{s}, \mathrm{H}-23, \mathrm{H}-24, \mathrm{H}-25, \mathrm{H}-26$ and H-27), 0.97 (3H, d, J=6.0 Hz, H-29) and $1.03(3 \mathrm{H}, \mathrm{d}, J=6.3 \mathrm{~Hz}, \mathrm{H}-30)$; ${ }^{13} \mathrm{C}-\mathrm{NMR}\left(\mathrm{C}_{5} \mathrm{D}_{5} \mathrm{~N}, 100 \mathrm{MHz}\right): \delta 39.1(\mathrm{C}-1), 28.1$ (C-2), 78.1 (C-3), 39.4 (C-4), 55.8 (C-5), 18.8 (C-6), 33.6 (C-7), 40.0 (C-8), 48.1 (C-9), 37.3 (C-10), 25.0 (C-11), 125.6 (C-12), 139.4 (C-13), 42.5 (C-14), 28.7 (C-15), 23.9 (C-16), 48.1 (C-17), 53.6 (C-18), 39.5 (C-19), 39.5 (C-20), 31.1 (C-21), 37.3 (C-22), 28.8 (C-23), 16.6 (C-24), 15.7 (C-25), 17.6 (C-26), 23.7 (C-27), 180.2 (C-28), 17.5 (C-29) and 21.5 (C-30).

Cell culture and UA treatment. The GBC-SD and NOZ cells were cultured in RPMI-1640 or high-glucose DMEM supplemented with $10 \% \mathrm{FBS}$ at $37^{\circ} \mathrm{C}$ in a $5 \% \mathrm{CO}_{2}$ humidified atmosphere, and routinely passaged at 2-3-day intervals.
UA was dissolved in DMSO to a $50 \mathrm{mM}$ stock concentration. The final DMSO concentration was accounted for $\leq 0.1 \%(\mathrm{v} / \mathrm{v})$. DMSO (0.05\%)-treated cells were used as a vehicle control.

Cell viability assay. A CCK-8 assay was performed to evaluate the effect of UA on cell viability. A total of $1.2 \times 10^{4}$ cells/well were seeded in 96-well plates overnight and then treated with varying concentrations of UA $(0,10,20,30,40,45$ and $50 \mu \mathrm{M})$. The cells were incubated for either 24 or $48 \mathrm{~h}$ at $37^{\circ} \mathrm{C}$ in a humidified incubator, following which $10 \mu \mathrm{lCCK}-8$ solution was added into each well and incubated for a further $1 \mathrm{~h}$. The absorbance was measured at $450 \mathrm{~nm}$ in each well using a microplate spectrophotometer (BioTek Instruments, Inc., Winooski, VT, USA). The results are presented as the mean values of three independent experiments performed over multiple days. Cell viability was calculated using the following formula: Cell viability $(\%)=[$ optical density (OD) of the experiment samples/OD of the control] x $100 \%$. The half maximal inhibitory concentration $\left(\mathrm{IC}_{50}\right)$ value of UA against the GBC-SD or NOZ cells was calculated using GraphPad Prism 5 (GraphPad Software, Inc., La Jolla, CA, USA).

Apoptosis assays. Cell apoptosis was detected using an Annexin V-FITC/PI Apoptosis Detection kit. In brief, the cells from the UA-treated $(10,30$ and $50 \mu \mathrm{M})$ and untreated groups were seeded in 6 -well plates $\left(1 \times 10^{6}\right.$ cells/well) and cultured for $24 \mathrm{~h}$. The cells were collected, washed with ice-cold PBS, and resuspended in binding buffer at a cell density of $1 \times 10^{6}$ cells $/ \mathrm{ml}$. The cells were stained with $5 \mu \mathrm{l}$ Annexin V-FITC and $10 \mu \mathrm{l}$ PI $(20 \mu \mathrm{g} / \mathrm{ml})$ and then incubated in the dark at $25^{\circ} \mathrm{C}$ for $15 \mathrm{~min}$. Apoptotic cells were analyzed by flow cytometry (CytoFlex; Beckman Coulter Inc., Brea, CA, USA). The percentage of apoptotic cells was analyzed using FlowJo software (version 9.8.3, FlowJo LLC, Ashland, OR, USA). The experiments were repeated three times.

Cell invasion assay. A cell invasion assay was performed using $8-\mu \mathrm{m}$ pore size Transwell chambers. The upper side of the Transwell filter inserts was coated with $80 \mu \mathrm{l}$ diluted (1:8 in serum-free medium) Matrigel in 24-well plates. The GBC-SD cells at a density of $1 \times 10^{5}$ cells/well were suspended in serum-free RPMI-1640 medium and added to the upper chambers containing various concentrations of UA $(10,30$ and $50 \mu \mathrm{M})$. The lower chambers were filled with $500 \mu \mathrm{l}$ RPMI-1640 medium containing 20\% FBS. After $24 \mathrm{~h}$, the non-invaded cells were removed, and the invasive cells were fixed with $95 \%$ ethanol, stained with $0.1 \%$ crystal violet and images were captured (magnification, x100) with a light microscope (XDS-1B inverted biological microscope, Chongqing Optical \& Electrical Instrument Co., Ltd., Chongqing, China). The assay was repeated in three independent experiments.

$R T^{2}$ profiler PCR arrays for apoptosis and invasion. In brief, cells from the UA-treated $(50 \mu \mathrm{M})$ and untreated groups were seeded in 6 -well plates $\left(1 \times 10^{6}\right.$ cells/well $)$ and cultured for $24 \mathrm{~h}$. Total RNA was extracted from each experimental group using TRIzol reagent and quantified by spectrophotometry. Subsequently, $1 \mu \mathrm{g}$ of total RNA was reverse transcribed with the PrimeScript ${ }^{\mathrm{TM}}$ RT Reagent kit, according to the manufacturer's protocol. $\mathrm{RT}^{2}$ Profiler 'human apoptosis' PCR arrays 

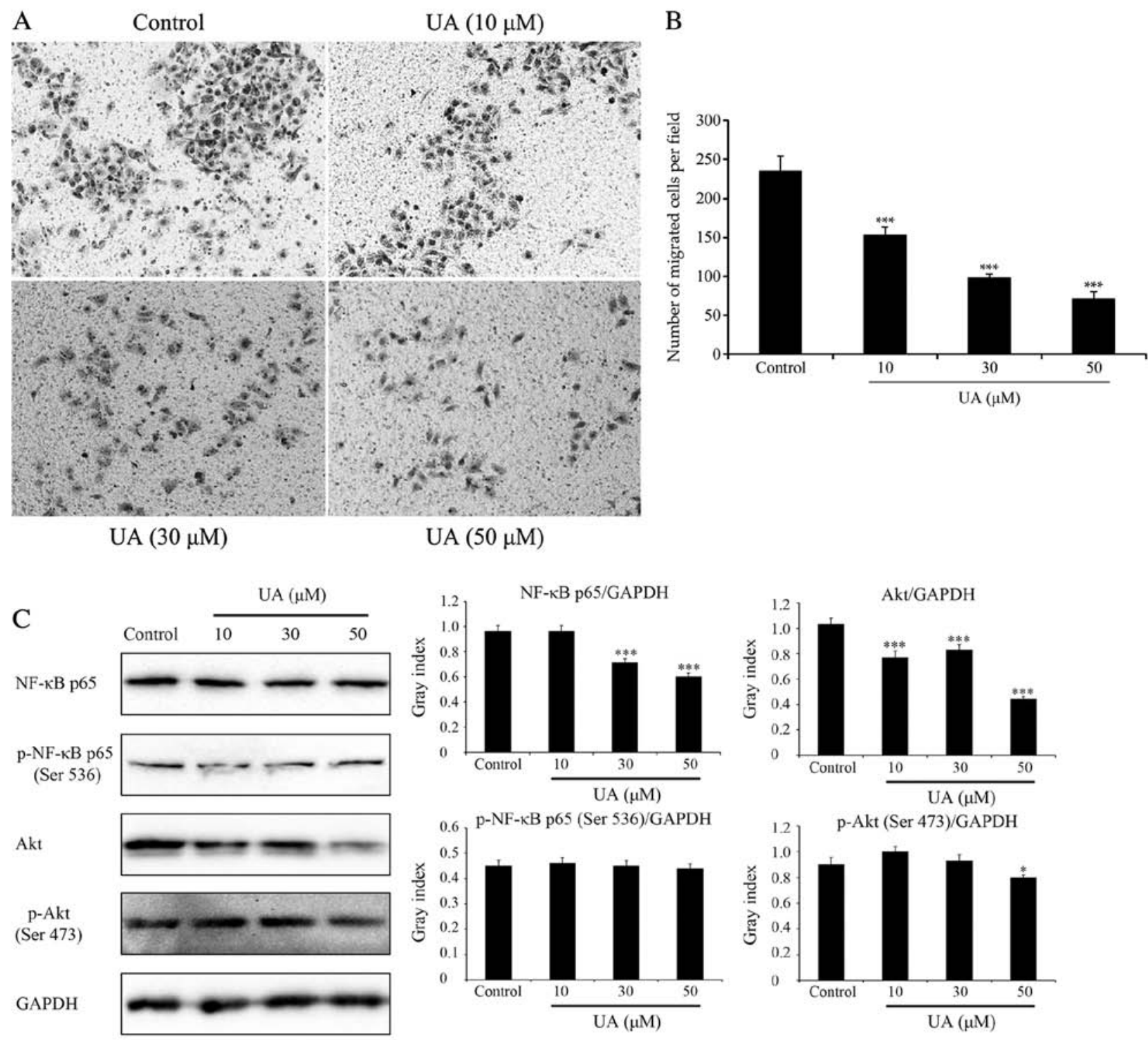

Figure 2. Effects of UA on cell migration and signaling pathways (NF-kB and Akt). Effects of UA on GBC-SD cell migration, evaluated using a Transwell assay. Cells suspended in serum-free RPMI-1640 were overlaid in the upper chamber of each Transwell. Following incubation with different concentrations of $\mathrm{UA}$ for $24 \mathrm{~h}$, penetrating cells were stained with crystal violet and recorded under a microscope mounted with a CCD camera. (A) Images depicting migration of GBC-SD cells. (B) Quantified data are expressed as the mean \pm standard deviation from three independent experiments. ${ }^{* * *} \mathrm{P}<0.001$, vs. control group $(0 \mu \mathrm{M})$. (C) Effect of UA treatment on the NF-kB and Akt signaling pathways. In GBC-SD cells treated with various UA concentrations for $6 \mathrm{~h}$, expression of NF-кB p65, p-NF-kB p65 (Ser536), Akt and p-Akt (Ser473) was analysed by western blotting. GAPDH was used as the sample loading control. Quantification of protein bands densitometry was carried out using ImageJ software. Data are presented as the mean \pm standard deviation from three independent experiments. " $\mathrm{P}<0.05$ and ${ }^{* * * *} \mathrm{P}<0.001$, vs. control group $(0 \mu \mathrm{M})$. UA, ursolic acid; NF- $\kappa \mathrm{B}$, nuclear factor $\kappa \mathrm{B}$; Akt, protein kinase B; p-, phosphorylated.

and $\mathrm{RT}^{2}$ Profiler 'human extracellular matrix and adhesion molecules' PCR arrays were performed in duplicate according to the manufacturer's protocol. The PCR was performed as follows: $10 \mathrm{~min}$ at $95^{\circ} \mathrm{C}$ and 40 cycles $\left(15 \mathrm{sec}\right.$ at $95^{\circ} \mathrm{C}, 1 \mathrm{~min}$ at $60^{\circ} \mathrm{C}$ ). The specificity of the SYBR Green assay was confirmed by melting curve analysis. Relative fold changes in mRNA levels were calculated following normalization to housekeeping control gene targets using the comparative $\mathrm{Cq}$ method (14).

Kyoto Encyclopedia of Genes and Genomes (KEGG) pathway analysis. In order to investigate the signaling pathways that may be involved in the effects of UA on GBC-SD cells, KEGG pathway analysis of differentially expressed genes was performed using the Database for Annotation, Visualization and Integrated Discovery (https://david.ncifcrf.gov/) $(15,16)$. Pathway terms with $\mathrm{P}<0.05$ were considered statistically significant.

Western blot analysis. Following treatment with UA $(0,10$, 30 and $50 \mu \mathrm{M}$ ) for $6 \mathrm{~h}$, the GBC-SD cells were washed with PBS and lysed in RIPA lysis buffer. Based on total protein concentrations calculated from the BCA assays, the total cell lysates (15 $\mu \mathrm{g}$ total protein) were separated via SDS-PAGE ( $8 \%$ gel) and then transferred onto polyvinylidene difluoride membranes in a standard transfer buffer. Following blocking with $1 \% \mathrm{BSA}$ (blocking solution) for $1.5 \mathrm{~h}$ at room temperature, the membranes were incubated with primary antibodies to 
Table I. Genes with >1.5-fold change in expression between GBC-SD cells treated with UA and the control group.

\begin{tabular}{|c|c|c|c|c|}
\hline $\begin{array}{l}\mathrm{RT}^{2} \text { profiler } \\
\mathrm{PCR} \text { arrays }\end{array}$ & $\begin{array}{l}\text { Gene } \\
\text { symbol }\end{array}$ & $\begin{array}{c}\text { GenBank } \\
\text { accession no. }\end{array}$ & Description & $\begin{array}{l}\log _{2} \text { fold } \\
\text { change }^{\mathrm{a}}\end{array}$ \\
\hline \multirow[t]{8}{*}{ Human apoptosis } & NOL3 & NM_003946 & $\begin{array}{l}\text { Nucleolar protein } 3 \text { (apoptosis repressor with } \\
\text { CARD domain) }\end{array}$ & -2.56 \\
\hline & LTA & NM_000595 & Lymphotoxin $\alpha$ (TNF superfamily, member 1) & 2.19 \\
\hline & TNFSF8 & NM_001244 & $\begin{array}{l}\text { Tumor necrosis factor (ligand) superfamily, } \\
\text { member } 8\end{array}$ & -1.87 \\
\hline & BCL2L2 & NM_004050 & BCL2-like 2 & -1.80 \\
\hline & BCL2A1 & NM_004049 & BCL2-related protein A1 & 2.50 \\
\hline & BCL2L10 & NM_020396 & BCL2-like 10 (apoptosis facilitator) & 2.60 \\
\hline & CD27 & NM_001242 & CD27 molecule & 3.56 \\
\hline & TNF & NM_000594 & Tumor necrosis factor & 3.17 \\
\hline \multirow{16}{*}{$\begin{array}{l}\text { Human } \\
\text { extracellular matrix } \\
\text { and adhesion molecules }\end{array}$} & COL11A1 & NM_080629 & Collagen, type XI, $\alpha 1$ & -2.90 \\
\hline & SELL & NM_000655 & Selectin L & -2.58 \\
\hline & MMP11 & NM_005940 & Matrix metallopeptidase 11 & -2.38 \\
\hline & MMP9 & NM_004994 & Matrix metallopeptidase 9 & -2.03 \\
\hline & MMP2 & NM_004530 & Matrix metallopeptidase 2 & -1.81 \\
\hline & SPARC & NM_003118 & Secreted protein, acidic, cysteine-rich (osteonectin) & -1.78 \\
\hline & VCAN & NM_004385 & Versican & -1.76 \\
\hline & FN1 & NM_002026 & Fibronectin 1 & 1.56 \\
\hline & ICAM1 & NM_000201 & Intercellular adhesion molecule 1 & 1.66 \\
\hline & ITGA2 & NM_002203 & Integrin, $\alpha 2$ & 1.68 \\
\hline & ITGA1 & NM_181501 & Integrin, $\alpha 1$ & 1.75 \\
\hline & PECAM1 & NM_000442 & Platelet/endothelial cell adhesion molecule & 2.16 \\
\hline & HAS1 & NM_001523 & Hyaluronan synthase 1 & 2.22 \\
\hline & KAL1 & NM_000216 & Kallmann syndrome 1 sequence & 2.26 \\
\hline & MMP10 & NM_002425 & Matrix metallopeptidase 10 & 4.41 \\
\hline & MMP1 & NM_002421 & Matrix metallopeptidase 1 & 4.79 \\
\hline
\end{tabular}

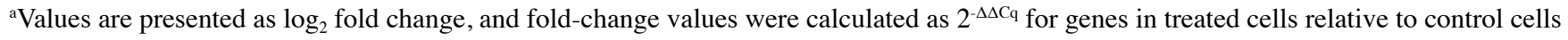

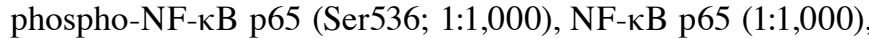
phospho-Akt (Ser473; 1:1,000), Akt $(1: 1,000)$ or GAPDH $(1: 5,000)$ overnight at $4^{\circ} \mathrm{C}$. The membranes were washed three times with TBST and then incubated with HRP-conjugated secondary antibodies (1:5,000; cat. no. SA00001-1/ SA00001-2; ProteinTech Group, Inc., Chicago, IL, USA) for $2 \mathrm{~h}$ at room temperature. Following extensive washing in TBST, the protein signals were visualized using enhanced chemiluminescence (ECL) western blotting substrate (cat. no. B500014; ProteinTech Group, Inc., Chicago, IL, USA) and an ECL system (Bio-Rad Laboratories, Inc., Hercules, CA, USA). Equal protein loading was assessed by normalizing against the expression of GAPDH. Quantification of protein bands densitometry was carried out using ImageJ software (version 1.8.0_112; National Institutes of Health, Bethesda, MD, USA).

Statistical analysis. All data are expressed as the mean \pm standard deviation. Statistical analysis was performed using SPSS 22.0 (IBM Corp., Armonk, NY, USA). Groups were compared using one-way analysis of variance. $\mathrm{P}<0.05$ was considered to indicate a statistically significant difference.

\section{Results}

Structural determination of UA isolated from I. excisoides and cell viability assay. Consistent with previous results $(17,18)$, UA was isolated from an Isodon species (I. excisoides). UA was identified by comparison of its HR-EIMS, ${ }^{1} \mathrm{H}-\mathrm{NMR}$ and ${ }^{13} \mathrm{C}-\mathrm{NMR}$ spectra data with those previously reported for UA $(19,20)$, and to an authentic sample (Sigma-Aldrich; Merck KGaA, Darmstadt Germany). The proliferation inhibition effect of UA on GBC-SD and NOZ cells was determined using a CCK- 8 assay. Within the dose range and time period measured, UA was able to inhibit cell proliferation in a doseand time-dependent manner (Fig. $1 \mathrm{~B}$ and $\mathrm{C}$ ). Furthermore, the $\mathrm{IC}_{50}$ values of UA at the same exposure time for GBC-SD cells were marginally lower compared with those for NOZ cells. The $\mathrm{IC}_{50}$ values for GBC-SD cells at 24 and $48 \mathrm{~h}$ were 57.44 and $39.12 \mu \mathrm{M}$, respectively, and the values for NOZ cells were 61.58 and $41.81 \mu \mathrm{M}$, respectively. Therefore, GBC-SD cells were selected to further investigate the effect of UA on the invasive capacity of GBC cells. In addition, the $\mathrm{IC}_{50}$ value for GBC-SD cells at $48 \mathrm{~h}$ was lower than that reported in the literature (for example, the $\mathrm{IC}_{50}$ value for GBC-SD cells at $48 \mathrm{~h}$ 
Table II. Kyoto Encyclopedia of Genes and Genomes pathway analysis of differentially expressed genes.

Term $^{\mathrm{a}}$

Genes

P-value

hsa04064: NF- $\mathrm{BB}$ signaling pathway

hsa05205: Proteoglycans in cancer

hsa04512: ECM-receptor interaction

hsa04668: TNF signaling pathway

hsa04670: Leukocyte transendothelial migration

hsa04514: Cell adhesion molecules (CAMs)

hsa05219: Bladder cancer

hsa05144: Malaria

hsa05200: Pathways in cancer

hsa04510: Focal adhesion

hsa05410: Hypertrophic cardiomyopathy (HCM)

hsa04060: Cytokine-cytokine receptor interaction

hsa05414: Dilated cardiomyopathy

hsa04640: Hematopoietic cell lineage

hsa05323: Rheumatoid arthritis

hsa04151: PI3K-Akt signaling pathway hsa05146: Amoebiasis

$\begin{array}{ll}\text { ICAM1, TNF, BCL2A1, LTA } & 0.001 \\ \text { TNF, MMP9, ITGA2, MMP2, FN1 } & 0.001 \\ \text { ITGA1, ITGA2, COL11A1, FN1 } & 0.001 \\ \text { ICAM1, TNF, MMP9, LTA } & 0.002 \\ \text { ICAM1, MMP9, PECAM1, MMP2 } & 0.002 \\ \text { ICAM1, SELL, PECAM1, VCAN } & 0.004 \\ \text { MMP9, MMP2, MMP1 } & 0.004 \\ \text { ICAM1, TNF, PECAM1 } & 0.006 \\ \text { MMP9, ITGA2, MMP2, MMP1, FN1 } & 0.011 \\ \text { ITGA1, ITGA2, COL11A1, FN1 } & 0.011 \\ \text { TNF, ITGA1, ITGA2 } & 0.014 \\ \text { TNF, CD27, LTA, TNFSF8 } & 0.015 \\ \text { TNF, ITGA1, ITGA2 } & 0.016 \\ \text { TNF, ITGA1, ITGA2 } & 0.016 \\ \text { ICAM1, TNF, MMP1 } & 0.017 \\ \text { TNF, COL11A1, FN1 } & 0.024 \\ \text { ITGA1, ITGA2, COL11A1, FN1 } & 0.043\end{array}$

a Pathway terms with $\mathrm{P}<0.05$ were considered statistically significant. was previously reported to be $47.6 \mu \mathrm{M}$ ) (13), which may derive from differences in experimental design and operation.

$U A$ induces apoptosis of GBC-SD cells in a dose-dependent manner. The UA-induced apoptosis of GBC-SD cells was determined using an Annexin V-FITC/PI assay. As indicated in Fig. 1D and E, UA treatment increased the apoptosis of GBC-SD cells in a dose-dependent manner. The apoptotic rates of the cells were $11.98,17.37$ and $55.50 \%$ following treatment with 10,30 and $50 \mu \mathrm{M} \mathrm{UA}$, respectively, which were all increased compared with the apoptotic rate of GBC-SD cells cultured under normal conditions $(9.96 \%)$. The apoptotic rates of GBC-SD cells in the middle $(30 \mu \mathrm{M})$ and high $(50 \mu \mathrm{M})$ dose groups were statistically significant $(\mathrm{P}<0.05)$. UA $(10,30$ or $50 \mu \mathrm{M})$ treatment had no significant effect on the distribution of GBC-SD cells in the cell cycle (data not shown). These results indicate that UA inhibits GBC-SD cell proliferation by inducing apoptosis.

$U A$ inhibits the invasion of GBC-SD cells in a dose-dependent manner. Cell invasion is a driving force in the process of tumor metastasis formation. Therefore, the effects of UA on invasion in GBC-SD cells was evaluated (Fig. 2A and B). The in vitro invasion assay indicated that $\mathrm{UA}$ at concentrations of $10-50 \mu \mathrm{M}$ significantly reduced the rate of GBC-SD cell invasion when compared with the control group following cell treatment for $24 \mathrm{~h}(\mathrm{P}<0.01)$. Furthermore, UA at concentrations of 10 and $30 \mu \mathrm{M}$ did not significantly reduce the viability of GBC-SD cells following cell treatment for $24 \mathrm{~h}$ (Fig. 1B). These results suggested that the inhibition of GBC-SD cell invasion by UA did not result from a reduction of cell viability. These observations suggested that UA was able to regulate the invasive capacity of GBC-SD cells in a dose-dependent manner.
Effects of UA on GBC-SD cells are at least in part via $N F-\kappa B$ and Akt signaling pathways. As UA induced apoptosis and inhibited invasion in GBC-SD cells, the expression of 168 key genes involved in these two processes was subsequently evaluated with a PCR array. The cells were incubated with UA $(50 \mu \mathrm{M})$ for $24 \mathrm{~h}$, and 168 related genes (84 apoptosis-related genes and 84 adhesion/invasion-related genes) were analyzed, compared with untreated GBC-SD cells. Of these 168 genes, there were 24 with $\log _{2}$ fold change values of either $>1.5$ or $\geq 1.5$, which were considered differentially expressed (Table I). Of these 24 genes, eight apoptosis-related genes were screened. Of these eight genes, three genes encoding pro-apoptotic members of the tumor necrosis factor (TNF) family, including TNF ( $\log _{2}$ fold change: 3.17$)$, lymphotoxin- $\alpha\left(\log _{2}\right.$ fold change: 2.19$)$ and CD27 ( $\log _{2}$ fold change: 3.56 ) were enhanced in the UA-treated GBC-SD cells compared with the control groups (Table I). Therefore, these results suggested that UA induces apoptosis in GBC-SD cells through activation of the cell extrinsic pathway, which is initiated by members of the TNF superfamily $(21,22)$. TNF is able to trigger either the formation of complex-I, driving the activation of NF- $\kappa \mathrm{B}$ and an inflammatory response, or the formation of complex-II, which can trigger apoptosis (23). Of the 24 differentially expressed genes, a further 16 adhesion/ invasion-related genes were screened out, including nine upregulated and seven downregulated genes. These upregulated and downregulated genes may have multiple effects on the invasion of GBC-SD cells. KEGG pathway analysis of the 24 differentially expressed genes was performed using the Database for Annotation, Visualization and Integrated Discovery $(15,16)$. According to KEGG pathway enrichment analysis, the differentially expressed genes were significantly associated with NF- $\kappa \mathrm{B}$, TNF, PI3K-Akt and other signaling pathways (Table II). To determine whether UA regulates the 
NF- $\mathrm{BB}$ and Akt signaling pathways, the effect of UA on the expression and activation of proteins in these signaling pathways was detected by western blotting. As shown in Fig. 2C, the GBC-SD cells treated with UA exhibited a significant and dose-dependent reduction in total NF- $\mathrm{KB}$ p65 and Akt, and a marginal decrease in total p-NF-kB p65 (Ser536) and p-Akt (Ser473). Therefore, it was demonstrated that the effects of UA on GBC-SD cells were, at least in part, mediated through the NF- $\kappa \mathrm{B}$ and Akt signaling pathways.

\section{Discussion}

UA is a pentacyclic triterpenoid widely found in the plant kingdom. It has attracted attention in recent years due to it numerous activities and low toxicity (10). It exerts anticancer effects in various cancer cell lines (24), and inhibits the growth of GBC cells through inducing cell cycle arrest and apoptosis (13). The present study identified that low doses of UA $(10,30$ and $50 \mu \mathrm{M})$ did not affect cell cycle but induced cell apoptosis in GBC-SD cells. In addition, previous studies have reported that UA can cause cell death by autophagy or necrosis $(25,26)$. These results indicate that UA inhibits GBC-SD cell proliferation primarily by inducing cell death via apoptosis, and possibly also via autophagy or necrosis. To the best of our knowledge, no previous studies have reported the anti-invasive effect of UA on GBC. It was identified in the present study that UA significantly reduced the rate of GBC-SD cell invasion. Furthermore, the effects of UA on GBC-SD cells were at least partly mediated via the suppression of NF- $\mathrm{KB}$ and Akt signaling pathways.

The anticancer mechanism of UA is complex and multifaceted. The results of the present study suggested that UA induced the apoptosis of GBC-SD cells through activation of the cell extrinsic pathway. However, a previous study demonstrated that activation of the mitochondrial-mediated apoptotic pathway is also involved in UA-induced GBC-SD cell apoptosis (13). Another study on gastrointestinal cancer demonstrated that UA modulates the expression of executioner caspase (C-3, C-8 and C-9) proteins involved in the intrinsic and extrinsic pathways of apoptosis (27). UA-induced apoptosis can be mediated by an increase in activated extracellular signal regulated kinase $1 / 2$, Janus kinase and p38 mitogen-activated protein kinase (28). UA-induced GBC-SD cell apoptosis may also be involved in the intrinsic and extrinsic pathways of apoptosis. In addition, inhibition of the NF- $\mathrm{kB}$ and Akt signaling pathways by UA has been reported in other cell types $(29,30)$, which is consistent with the present study. The pro-survival Akt and NF- $\mathrm{\kappa B}$ signaling pathways are constitutively activated in several types of cancer, and contribute to cancer development and progression. The anticancer effects of certain dietary natural compounds are mediated by targeting the Akt and NF- $\mathrm{KB}$ pathways $(31,32)$. The NF- $\mathrm{\kappa B}$ pathway also has the ability to cross-talk with Akt pathways in various cancer types. The suppression of Akt may contribute to inhibiting downstream targets, including NF- $\mathrm{BB}$ p-65 and the mRNA levels of matrix metalloproteinase 2 (MMP2) and MMP9 in GBC-SD cells (33). These two genes were downregulated in the present study (Table I) and are critical to tumor invasion. Certain clinical studies with a small number of patients have demonstrated the safety and efficacy of UA in cancer therapy (11). Future investigations are required to analyze the precise mechanisms of UA and to exploit its full potential for GBC chemotherapy.

In conclusion, UA was isolated from I. excisoides. The antiproliferative and anti-invasive effects of UA in GBC-SD cells were investigated and validated. Furthermore, UA was demonstrated to induce apoptosis and inhibit invasion in GBC-SD cells, which may be associated with the suppression of NF- $\kappa \mathrm{B}$ and Akt signaling pathways. The effects of UA in GBC-SD cells suggest that UA may be a candidate agent for the chemoprevention and/or treatment of GBC progression.

\section{Acknowledgements}

The authors would like to thank Professor Jicheng Li (Zhengzhou University, Zhengzhou, China) for assistance with authenticating the plant material.

\section{Funding}

The present study was financially supported by the Medical Science and Technology Planning Project of Henan Province, China (grant no. 201702299), the Major Special Science and Technology Projects of Henan Province, China (grant no. 161100311400) and the Natural Science Foundation of Henan Province, China (grant no. 182300410343).

\section{Availability of data and materials}

The datasets used and/or analyzed during the current study are available from the corresponding author on reasonable request.

\section{Authors' contributions}

YD and JZ designed the experiments and wrote the manuscript. $\mathrm{HC}$ and $\mathrm{XW}$ performed the majority of the experiments. DZ, $\mathrm{MZ}$ and $\mathrm{ZZ}$ were involved in chemical research and analyzed the data. $\mathrm{XZ}$ and $\mathrm{XY}$ were involved in data interpretation and assisted in drafting the manuscript. All authors read and approved the final manuscript.

\section{Ethics approval and consent to participate}

Not applicable.

\section{Patient consent for publication}

Not applicable.

\section{Competing interests}

The authors declare that they have no competing interests.

\section{References}

1. Zhu AX, Hong TS, Hezel AF and Kooby DA: Current management of gallbladder carcinoma. Oncologist 15: 168-181, 2010

2. Sharma A, Sharma KL, Gupta A, Yadav A and Kumar A: Gallbladder cancer epidemiology, pathogenesis and molecular genetics: Recent update. World J Gastroenterol 23: 3978-3998, 2017. 
3. Aloia TA, Járufe N, Javle M, Maithel SK, Roa JC, Adsay V, Coimbra FJ and Jarnagin WR: Gallbladder cancer: Expert consensus statement. HPB (Oxford) 17: 681-690, 2015.

4. Kanthan R, Senger JL, Ahmed S and Kanthan SC: Gallbladder cancer in the 21st century. J Oncol 2015: 967472, 2015.

5. Sun HD, Huang SX and Han QB: Diterpenoids from Isodon species and their biological activities. Nat Prod Rep 23: 673-698, 2006.

6. Wang F, Li XM and Liu JK: New terpenoids from Isodon sculponeata. Chem Pharm Bull (Tokyo) 57: 525-527, 2009.

7. Jiao K, Li HY, Zhang P, Pi HF, Ruan HL and Wu JZ: Three new ursane-type triterpenoids from the aerial parts of Isodon excisoides. J Asian Nat Prod Res 15: 962-968, 2013.

8. Huang H, Sun $\mathrm{H}$ and Zhao S: Flavonoids from Isodon oresbius. Phytochemistry 42: 1247-1248, 1996.

9. Kashyap D, Tuli HS and Sharma AK: Ursolic acid (UA): A metabolite with promising therapeutic potential. Life Sci 146 201-213, 2016.

10. López-Hortas L, Pérez-Larrán P, González-Muñoz MJ, Falqué E and Domínguez H: Recent developments on the extraction and application of ursolic acid. A review. Food Res Int 103: 130-149, 2018.

11. Prasad S, Tyagi AK and Aggarwal BB: Chemosensitization by ursolic acid: A new avenue for cancer therapy. In: Role of nutraceuticals in cancer chemosensitization. Bharti AC and Aggarwal BB (eds). Academic Press, Cambridge, Massachusetts, pp99-109, 2018

12. He W, Shi F, Zhou ZW, Li B, Zhang K, Zhang X, Ouyang C, Zhou SF and Zhu X: A bioinformatic and mechanistic study elicits the antifibrotic effect of ursolic acid through the attenuation of oxidative stress with the involvement of ERK, PI3K/Akt, and p38 MAPK signaling pathways in human hepatic stellate cells and rat liver. Drug Des Devel Ther 9: 3989-4104, 2015.

13. Weng H, Tan ZJ, Hu YP, Shu YJ, Bao RF, Jiang L, Wu XS Li ML, Ding Q, Wang XA, et al: Ursolic acid induces cell cycle arrest and apoptosis of gallbladder carcinoma cells. Cancer Cell Int 14: 96, 2014.

14. Livak KJ and Schmittgen TD: Analysis of relative gene expression data using real-time quantitative PCR and the 2(-Delta Delta C(T)) method. Methods 25: 402-408, 2001.

15. Huang da W, Sherman BT and Lempicki RA: Bioinformatics enrichment tools: Paths toward the comprehensive functional analysis of large gene lists. Nucleic Acids Res 37: 1-13, 2009.

16. Huang da W, Sherman BT and Lempicki RA: Systematic and integrative analysis of large gene lists using DAVID bioinformatics resources. Nature Protoc 4: 44-57, 2009.

17. Yang YC, Wei MC and Huang TC: Optimisation of an ultrasound-assisted extraction followed by RP-HPLC separation for the simultaneous determination of oleanolic acid, ursolic acid and oridonin content in Rabdosia rubescens. Phytochem Anal 23: 627-636, 2012

18. Jiang B, Hou AJ, Li ML, Li SH, Han QB, Wang SJ, Lin ZW and Sun HD: Cytotoxic ent-kaurane diterpenoids from Isodon sculponeata. Planta Med 68: 921-925, 2002.
19. Ali MS, Ibrahim SA, Jalil S and Choudhary MI: Ursolic acid: A potent inhibitor of superoxides produced in the cellular system. Phytother Res 21: 558-561, 2007.

20. Seebacher W, Simic N, Weis R, Saf R and Kunert O: Complete assignments of ${ }^{1} \mathrm{H}$ and ${ }^{13} \mathrm{C}$ NMR resonances of oleanolic acid, $18 \alpha$-oleanolic acid, ursolic acid and their 11-oxo derivatives. Magn Reson Chem 41: 636-638, 2003.

21. Fulda S and Debatin KM: Extrinsic versus intrinsic apoptosis pathways in anticancer chemotherapy. Oncogene 25: 4798-4811, 2006.

22. Savva CG, Totokotsopoulos S, Nicolaou KC, Neophytou CM and Constantinou AI: Selective activation of TNFR1 and NF- $\mathrm{KB}$ inhibition by a novel biyouyanagin analogue promotes apoptosis in acute leukemia cells. BMC Cancer 16: 279, 2016.

23. Annibaldi A and Meier P: Checkpoints in TNF-induced cell death: Implications in inflammation and cancer. Trends Mol Med 24: 49-65, 2018.

24. Woźniak Ł, Skapska S and Marszałek K: Ursolic acid-A pentacyclic triterpenoid with a wide spectrum of pharmacological activities. Molecules 20: 20614-20641, 2015.

25. Jung J, Seo J, Kim J and Kim JH: Ursolic acid causes cell death in PC-12 cells by inducing apoptosis and impairing autophagy. Anticancer Res 38: 847-853, 2018.

26. Lu CC, Huang BB, Liao PJ and Yen GC: Ursolic acid triggers nonprogrammed death (necrosis) in human glioblastoma multiforme DBTRG-05MG cells through MPT pore opening and ATP decline. Mol Nutr Food Res 58: 2146-2156, 2014.

27. Wang X, Zhang F, Yang L, Mei Y, Long H, Zhang X, Zhang J, Qimuge-Suyila, and Su X: Ursolic acid inhibits proliferation and induces apoptosis of cancer cells in vitro and in vivo. J Biomed Biotechnol 2011: 419343, 2011.

28. Wu CC, Cheng CH, Lee YH, Chang IL, Chen HY, Hsieh CP and Chueh PJ: Ursolic acid triggers apoptosis in human osteosarcoma cells via caspase activation and the ERK1/2 MAPK pathway. J Agric Food Chem 64: 4220-4226, 2016.

29. Meng Y, Lin ZM, Ge N, Zhang DL, Huang J and Kong F: Ursolic acid induces apoptosis of prostate cancer cells via the PI3K/Akt/ mTOR pathway. Am J Chin Med 43: 1471-1486, 2015.

30. Gai L, Cai N, Wang L, Xu X and Kong X: Ursolic acid induces apoptosis via Akt/NF-kB signaling suppression in T24 human bladder cancer cells. Mol Med Rep 7: 1673-1677, 2013.

31. Zhang L, Wen X, Li M, Li S and Zhao H: Targeting cancer stem cells and signaling pathways by resveratrol and pterostilbene. Biofactors 44: 61-68, 2018.

32. Wang L, Yue Z, Guo M, Fang L, Bai L, Li X, Tao Y, Wang S, Liu Q, Zhi D and Zhao H: Dietary flavonoid hyperoside induces apoptosis of activated human LX-2 hepatic stellate cell by suppressing canonical NF- $\kappa \mathrm{B}$ signaling. Biomed Res Int 2016: 1068528,2016

33. Cui H, Yuan J, Du X, Wang M, Yue L and Liu J: Ethyl gallate suppresses proliferation and invasion in human breast cancer cells via Akt-NF-אB signaling. Oncol Rep 33: 1284-1290, 2015. 